\title{
The effect of choice options in training curricula on the supply of and demand for apprenticeships
}

Citation for published version (APA):

Jansen, A., de Grip, A., \& Kriechel, B. (2016). The effect of choice options in training curricula on the supply of and demand for apprenticeships. Maastricht University, Graduate School of Business and Economics. GSBE Research Memoranda No. 009 https://doi.org/10.26481/umagsb.2016009

Document status and date:

Published: 01/01/2016

DOI:

10.26481/umagsb.2016009

Document Version:

Publisher's PDF, also known as Version of record

\section{Please check the document version of this publication:}

- A submitted manuscript is the version of the article upon submission and before peer-review. There can be important differences between the submitted version and the official published version of record. People interested in the research are advised to contact the author for the final version of the publication, or visit the DOI to the publisher's website.

- The final author version and the galley proof are versions of the publication after peer review.

- The final published version features the final layout of the paper including the volume, issue and page numbers.

Link to publication

\footnotetext{
General rights rights.

- You may freely distribute the URL identifying the publication in the public portal. please follow below link for the End User Agreement:

www.umlib.nl/taverne-license

Take down policy

If you believe that this document breaches copyright please contact us at:

repository@maastrichtuniversity.nl

providing details and we will investigate your claim.
}

Copyright and moral rights for the publications made accessible in the public portal are retained by the authors and/or other copyright owners and it is a condition of accessing publications that users recognise and abide by the legal requirements associated with these

- Users may download and print one copy of any publication from the public portal for the purpose of private study or research.

- You may not further distribute the material or use it for any profit-making activity or commercial gain

If the publication is distributed under the terms of Article $25 \mathrm{fa}$ of the Dutch Copyright Act, indicated by the "Taverne" license above, 
Anika Jansen, Andries de Grip, Ben Kriechel

The effect of choice options in training curricula on the supply of and demand for apprenticeships

RM/16/009

\section{GSBE}

Maastricht University School of Business and Economics

Graduate School of Business and Economics

P.O Box 616

NL- 6200 MD Maastricht

The Netherlands 


\title{
The effect of choice options in training curricula on the supply of and demand for apprenticeships ${ }^{1}$
}

\author{
Anika Jansen $^{1,2}$, Andries de Grip ${ }^{2,3}$, Ben Kriechel ${ }^{4,2}$ \\ 1: BIBB, Bonn, Germany, 2: ROA, Maastricht University, the Netherlands, 3: IZA, Bonn, Germany, 4: \\ ERC, München, Germany
}

\begin{abstract}
Building on Lazear's skill weights approach, we study the effect of having more or less heterogeneity in the training curriculum on supply of and demand for apprenticeship training. Modernizations of training curricula provide us with a quasi-experimental setting as these modernizations can be seen as a relatively exogenous shock. We argue that firms will train more apprentices when they have more choice options in the training curriculum because of (1) the higher productivity of graduates who have acquired more skills that are relevant for the firm, and (2) firms' higher market power in the wage bargaining process with graduates. We test this hypothesis on data on the supply of apprenticeship places in Germany in all occupations from 2004 to 2014. We find that a more heterogeneous curriculum increases both firms' supply of and students' demand for training places.
\end{abstract}

Anika Jansen

Federal Institute for Vocational

Education and Training

Robert Schuman Platz 5

53175 Bonn

Germany

jansen@bibb.de
Andries de Grip

Maastricht University

ROA / Department of Economics

P.O. Box 616

NL-6200 MD Maastricht

The Netherlands

a.degrip@maastrichtuniversity.nl
Ben Kriechel,

Economix Research \&

Consulting

Lindwurmstraße 9

80337 München

Germany

ben.kriechel@economix.org

\footnotetext{
${ }^{1}$ We thank Thomas Zwick, Maria Polipciuc, and Wendy Smits for comments and valuable suggestions.
} 


\section{Introduction}

The dual apprenticeship system in Germany plays an important role in integrating young people into the labor market and in safeguarding a skilled workforce. More than $50 \%$ of each cohort starts an apprenticeship program each year (Uhly 2015). As firms can freely decide whether they provide training places or not, it is important to understand the incentives and conditions under which firms are willing to supply training places. The analysis of the supply of apprenticeship places has so far focused on demographic developments, the business cycle, and alternative recruitment possibilities on the external labor market (Troltsch \& Walden 2010; Mühlemann et al. 2009; Dietrich \& Gerner 2007; Maier \& Walden 2014). However, none of these studies has related firms' supply of training places to the content of the training curriculum.

According to the German Vocational Training Act ${ }^{2}$, training firms have to impart a predetermined set of skills defined in a standardized curriculum when providing training places in a recognized occupation of the dual system. While some occupations allow for specialization opportunities in their training curriculum, apprenticeship training courses for other occupations are designed as "mono-occupations", in which every firm has to teach exactly the same skills. However, due to technological and organizational developments, training curricula are sometimes modernized. ${ }^{3}$ A modernization of the training curriculum for a particular occupation often does not only change the content of the curriculum but also changes the choice options training firms have. Since the 1990s, for example, a tendency towards more heterogeneity in the training curricula could be seen (Demgenski \& Icks 2003; Bretschneider \& Schwarz 2011). In this paper, we use these relatively exogenous changes in the regulatory framework of apprenticeship training to assess the impact of having choice options on firms' supply of apprenticeship places as well as on youngsters' willingness to enroll in certain occupations within the dual apprenticeship system ${ }^{4}$.

A more tailor-made training content enables firms to train their apprentices in a way which is more closely aligned to what the firm really needs. This will render the apprentice

\footnotetext{
${ }^{2}$ See $\$ 4(2)$ of German Vocational Training Act

${ }^{3}$ The initiative for curricula modernizations usually starts from professional associations, the central employer organization, unions or the Federal Institute for Vocational Education and Training. For more information about the development and process of training regulations see Bundesinstitut für Berufsbildung (2014b).

${ }^{4}$ The exact year a new curriculum is implemented can be seen as relatively random. Moreover, by including year dummies and occupation-specific time trends, we can rule out a substantial amount of potential endogeneity.
} 
more productive both during the training period and after completion of training, whereas training which is closer to the production process of the firm is less complicated to organize, something which could reduce training costs. Moreover, a more specialized curriculum increases the market power of the training firm because apprentices who have completed training can only apply their skills in fewer outside firms. As a result, firms are able to pay lower wages upon the retention of the trainees, something which increases their incentives to provide apprenticeship places.

From the firms' perspective, the positive aspects of having more choice options seem to be undisputed. The results of a firm survey conducted on behalf of the former German Federal Ministry of Economics and Labor in 2005 (Ramboll Management 2005) indicate that different aspects of the training curricula, such as content and structure, play a crucial role in a firm's decision on whether or not to offer apprenticeship places. Indeed, 53\% of all nontraining firms state that allowing for more freedom in the training organization would ease the initiation of training (Schönfeld et al. 2010) ${ }^{5}$. Demgenski \& Icks (2003) also argue that too restrictive training curricula can be a severe obstacle to providing training. They show that $54 \%$ of former training firms see the lack of specialization opportunities as a huge impediment to continuing to provide apprenticeship training. Having choice options in the curriculum is therefore likely to increase firms' commitment to apprenticeship training.

Apprentices, on the other hand, do not necessarily have the same interests as the firms that offer apprenticeships. More specialized training means that apprentices who have completed training have worse chances of finding a job in other firms because their skills then only match the skill demands of fewer other firms. If apprentices are not sure whether they will be retained upon completion of training, too specialized a curriculum may not be attractive for them. However, a more specialized training can also make the apprentice more productive in the training firm as the imparted skills correspond more closely to the firms' skill needs in the production process. If the higher productivity is to some extent reflected in a higher wage, the introduction of more choice options for firms could also increase the attractiveness of training from the apprentice's point of view.

In this paper, we explain the development of the supply ${ }^{6}$ of and demand for apprenticeship places after the introduction of more or fewer choice options in the course of a modernization. Assuming that training costs do not increase, the number of firms providing apprenticeship training will increase in line with increasing post-training benefits.

\footnotetext{
${ }^{5}$ This question was only asked to firms that currently do not offer training places.

${ }^{6}$ According to the wording of the data set, the term "supply" here refers to apprenticeship places and not to the supply of labor.
} 
Using data on the supply of and demand for apprenticeship places in Germany for 271 occupations over 11 years, we analyze the effect of curricula modernizations on training supply and demand empirically. The information about the modernization of the training curriculum is obtained by comparing the training curricula before and after modernizations. In total, 86 modernizations were analyzed. Our empirical analyses show that both supply of and demand for apprenticeships are positively affected by the introduction of more choice options in the training curriculum. This shows that leaving sufficient freedom in the training regulation improves the attractiveness of the dual system for firms as well as apprentices.

Our study contributes to the human capital literature on training by analyzing the effect of curriculum heterogeneity on the supply of and demand for apprenticeship places. The heterogeneity of training curricula might be an important aspect of the firms' willingness to train. This issue is highly relevant for designing (new) training regulations, within existing apprenticeship systems as well as for countries that aim to introduce elements of an apprenticeship system. Taking this knowledge into account can ensure the attractiveness of the apprenticeship system both from the firms' and the students' points of view. The insights provided in this paper can also be transferred to other centrally regulated or certified training courses.

The paper is structured as follows. In the next section, we discuss the relevant literature that provides the theoretical background to our empirical analysis. Section 3 presents the hypotheses on the effect of modernizations on the supply of training places and elaborates on the relation to the demand for training places. Section 4 discusses the data and explains how the degree of choice options of the curricula is ordered. Section 5 presents the empirical strategy to test the derived hypotheses and section 6 presents the results. Section 7 concludes.

\section{Literature}

While some firms train because they want to make use of the productive contribution of the apprentices, other firms decide to offer training places mainly because they want to retain the apprentices as skilled workers after the training period (Merrilees 1983). In the former case, firms actually do not bear any training costs as the productive contributions already compensate for the training expenses. In the latter case, firms regard the training costs as an investment, which they can recoup upon the retention of the apprentices. As rational firms only decide to train when expected benefits exceed expected costs, firms need to be able to pay a wage below skilled workers' productivity in order to recoup their training costs. However, paying a wage below workers' productivity is only possible when the firm has a certain market power over its employee. Becker (1962) showed that firms have no incentives to pay for training in general human capital. If firms then pay a wage below a 
worker's productivity after the training, the employee would leave the training firm and find a firm that offers a wage equal to his or her productivity. Firm-specific human capital, in contrast, can only be utilized in the training firm. Therefore, firms are only willing to invest in firm-specific human capital. Acemoglu \& Pischke (1999b; 1999a), however, expand Becker's theory by arguing that in non-competitive labor markets under the existence of wage compression, firms are also willing to pay for general human capital. Dionisius et al. (2009) showed that Germany is such a case, where the compressed wage structure leads to substantial post-training benefits, and in the same way to a willingness to incur training costs. As most occupations are associated with net training costs (see Schönfeld et al. 2010), one can expect post training benefits for most occupations ${ }^{7}$.

Stevens (1994) identifies a third group of skills, which she terms as transferable skills. Although these skills can be deployed in more firms, and are thus, technically seen, general skills, the wage does not have to equal the productivity of the person who has completed training because of the low degree of competition for these skills. Occupation-specific skills are a clear example of such transferable skills. Occupation-specific human capital denotes a set of skills that are merely useful within one occupation. Wolter \& Ryan (2011) explain that these occupation-specific skills create monopsony power for the training firm as they limit the number of potential outside firms where trained workers could employ their skills. ${ }^{8}$ As a result, workers' productivity related to these occupational skills is not fully reflected in their wages. Also Bhaskar et al. (2002) argue that when employers have some market power, they may have an incentive to pay for general human capital as the skilled worker wage will be lower than their marginal product. The more market power a firm has, i.e. the fewer firms where skilled employees could move to, the more likely firms are, ceteris paribus, to invest in training. Smits (2007) shows that, firms would only prefer to convey occupation- or industry-specific skills if it was not regulated otherwise. Even if workers paid for general skills, firms have no interest in providing workers with general training because the returns to industry-specific skills decrease with the share of general human capital.

Lazear (2009) argues that skills can be de facto firm specific, even if they are technically general, when the combinations of these general skills are specific to firms. He terms this concept the "skill weights approach" as each general skill has different weights in different firms. One essential outcome of the skill weights approach (SWA) is that firms that use more idiosyncratic skill weights, i.e. a combination of skills that is very different to the average combination of skills in other firms, are more willing to bear training costs as they can pay

\footnotetext{
${ }^{7}$ Schönfeld et al. (2010) analyzed the training costs from the 50 most important occupations.

${ }^{8}$ Also other sources of monopsony power can exist such as a low regional density of firms.
} 
relatively lower wages after the training period. Lazear notes that the specificity of the skill combination does not necessarily mean that it is specific to one firm. It can also be related to industries, occupations, or specific jobs. Translated into occupation specific skills, this would imply that firms training in occupations in which the required skills are very idiosyncratic are more likely to bear training costs. Geel et al. (2011) test this hypothesis and indeed find that more idiosyncratic skill weights in an occupation imply higher training investments on the part of the firms. This mechanism is supported by the finding of Hofmann et al. (2011), who analyze the effect of specificity of occupations on the probability that workers change their occupation. In accordance with the concept of the skill weights approach, they find that the more specific an occupation is, the less likely it is that employees change their occupation.

While these analyses focus on the mobility between different occupations, mobility within occupations to other firms is likely to be a greater threat for the training firm. The German labor market is very occupation specific and one can safely assume that, unless an unexpected change occurs, apprentices plan to stay in their occupation upon completion of training. Hall (2015) finds that in the first year after completion of training fewer than $4 \%$ of all apprentices switch to an occupation that is not related at all to the occupation in which they have been trained. $24 \%$ switch towards a related occupation, whereas $72 \%$ of all apprentices stay in the occupation they have learned. For comparison, data from the costbenefit survey show that $56 \%$ of all apprentices do not leave the training firm within the first year upon of completion of training ${ }^{9}$. Thus, mobility of persons successfully completing training to other firms within an occupation is also of high importance. However, also within an occupation, there could be quite some variation in the production process. ${ }^{10}$ Firms may have apprenticeship places for the same occupation but have different specializations. An occupation could, for example, need two main skills, but not all firms in this occupation might need these two skills to the same degree. Thus, firms training apprentices in the same occupation could also differ with respect to the weights they give to certain skills. Accordingly, Lazear's SWA can also be applied to the distribution of skill weights within an occupation. If firms could choose the training content freely, they would only train those skills that are relevant for their own production process. However, in the institutional setting of the German apprenticeship system, strict training curricula dictate the skills the firms have to provide during training.

Therefore, Lazear's skill weights approach does not fully match the settings of the German apprenticeship system. The skills, which are the main choice variables in Lazear's

\footnotetext{
${ }^{9}$ Own calculation on the data

${ }^{10}$ Even though the variation within an occupation might be lower than the variation between occupations.
} 
model, cannot be freely chosen in the case of apprenticeship training. However, in the last years, modernizations in training curricula have often given more freedom to training firms by including more choice and specialization options in the curricula, which allow the firms to train their apprentices in a way which is more closely related to their production process. In terms of the SWA, this means that firms can choose their skills more in line with what they would do if they could freely maximize their surplus. Creating more choice options in apprenticeship training also means that persons successfully completing training can apply their skills in fewer outside companies, which gives training firms more market power. This implies that firms can retain a higher share of the workers' productivity by paying lower wages, which leads to an increase in the expected long term benefits of training for the firms. Assuming that training costs do not increase, the introduction of choice options in the training curriculum will therefore lead to more apprenticeship places.

\section{Theory and hypothesis}

A modernization of an occupation means that the content of its training curriculum is changed. In this case, the old training curriculum is replaced by a new one. A modernization is commenced when any of the relevant stakeholders request an adjustment of the training content to technological developments. Usually, the duration of such a procedure lasts about a year (Bundesinstitut für Berufsbildung 2014). In most modernizations, the structure, i.e. the amount of choice options in the curricula, is also adjusted to the needs of the training firms (Table 1 in Section 4 provides an overview of the frequency of the different types of curriculum modernizations). In this section, we will outline the expected effect of a modernization on the supply of apprenticeship places in this occupation and briefly elaborate on the relation between modernizations and students' demand for apprenticeships.

\subsection{Supply of training places}

In our analyses, we will differentiate between the effect of a modernization as such, in the sense of an adjustment of the training content, and the effect of a change in the number of choice options training firms have. Firstly, we outline the hypothesis on changes of the content of the curricula irrespective of the degree of differentiation. Secondly, we discuss the effect of having more or fewer choice options. We argue that a more specific training curriculum will increase the productivity of the graduates and enable the firm to pay a relatively lower wage.

\subsubsection{Effect of changing the content of training curricula}

A modernization of the content of the curriculum always implies an adaption of the training curricula to technological developments. Therefore, modernizations align more closely the skills learned in the training with the skills demanded in the occupation and thus make apprenticeship training more effective. As a result, workers who successfully complete 
modernized apprenticeship training will ceteris paribus be more productive. If workers and employers equally share the returns on this additional productivity, firms have more incentives to train and workers are more likely to opt for a modernized occupation. As long as the wage increases less than graduate's productivity ${ }^{11}$, the return for the training firms increases. This will induce them to offer more training places. This leads to the following hypothesis:

H1: A modernization of the training curriculum leads to a higher supply of apprenticeship places in this occupation.

\subsubsection{Effect of more and less heterogeneity within the curriculum}

Apart from the adaption to technological development, a modernization is often associated with a change in the number of choice options in the curriculum. More choice options would then lead to more heterogeneity, while fewer choice options lead to less heterogeneity in the curriculum. The effect of heterogeneity on firms' post-training benefits can work via two mechanisms. Firstly, the degree of heterogeneity has a positive effect on the productivity of apprentices who have successfully completed training. Secondly, the degree of heterogeneity has a positive effect on the firms' market power. Both mechanisms will be outlined below.

\section{Effect via the productivity of apprentices successfully completing training}

In order to explain the effect of heterogeneity on the productivity of apprentices who have successfully completed training, we employ elements of the argumentation in Lazear's skill weights approach. Similarly to Lazear's skill weight model, we assume that (1) a firm i in a given occupation produces with the skills $A$ and $B$, and (2) that firms employing workers with this occupation need different combinations of these two skills. The weight for skill $A$ in firm i is denoted with $\lambda_{\mathrm{i}}$, which ranges from 0 to $1 . \lambda_{\mathrm{i}}$ is a random variable with the density

\footnotetext{
${ }^{11}$ For now, it can be assumed that the rent the firm retains is a constant share of a worker's productivity. Acemoglu and Pischke (1999) also argue that for higher training incentives it is not necessary that the share of a worker's productivity that the firm retains increases. Even if the firm retains a constant share of the worker's productivity as a rent, post-training benefits are higher for more productive workers as the "firm obtains a share of this larger pie" (p.121). Later, we will relax this assumption in the way that the share of the wage in relation to the productivity decreases. Then, the effect on firm-sponsored training will be even stronger.
} 
function $f\left(\lambda_{i}\right) .{ }^{12}$ The worker's production function in firm i depends on the worker's skills $A$ and $B$, and is as follows ${ }^{13}$ :

$$
Y_{i}=\left(\mathrm{A} \cdot \lambda_{i}\right)^{(1 / 2)}+\left[\mathrm{B} \cdot\left(1-\lambda_{i}\right)\right]^{1 / 2}
$$

Moreover, each firm has a maximum total training time for an apprentice, which has to be split between the two skills $A$ and $B$. Assume that $\alpha$ represents the time allocation between skills $A$ and $B$ and lies between 0 and 1 . Then, the time available for learning skill $A$ is equal to $\alpha$ and the time available for skill $B$ is equal to $1-\alpha$. Then, the production function could be written as a function of the allocation of training time to the two skills:

$$
Y_{i}=\left(\alpha \cdot \lambda_{i}\right)^{(1 / 2)}+\left[(1-\alpha) \cdot\left(1-\lambda_{i}\right)\right]^{1 / 2}
$$

The production function is designed in such a way that the worker is most productive if the training time for skill $A(\alpha)$ equals the firm's skill requirement $\lambda_{i}$. The higher the difference between $\alpha$ and $\lambda_{i}$, the lower the worker's productivity in firm $i$ will be. If firms could freely maximize their surplus, they would choose $\alpha$ equal to $\lambda_{i}$.

However, in contrast to Lazear's model, in German apprenticeship training time allocation $\alpha$ between the skills $A$ and $B$ is externally determined by the training curricula. As firms' training decisions depend on the expected productivity of the trained workers, this setting implies that firms' training decisions depends on the $\alpha$ set in the curriculum. The lower the difference between $\alpha$ and $\lambda_{i}$, the more likely it is that the firm will invest in training. As this is true for any individual firm, the supply of training places in a given occupation rise in line with lower aggregated differences between the skill requirement and the skills prescribed in the training curricula $\int_{i}^{N} \alpha-\lambda_{i}$, where $\mathrm{N}$ is the total number of firms.

In a mono-occupation, $\alpha$ is the same for all firms. If there are choice options in the training curriculum then firms can chose between several $\alpha$, i.e. specialization opportunities. To predict the effect of a change in the heterogeneity of the training curriculum, one needs to know in which case total productivity is highest. This depends on the amount and type of the choice options $\alpha$ and on the distribution of the production processes of the firms employing trained persons in the occupation: $\lambda_{i}$. Creating more heterogeneity in the curriculum will have a positive effect on aggregated productivity if firms' production processes are characterized by a strong specialization of skills. However, less heterogeneity

\footnotetext{
${ }^{12}$ In the extreme case, a firm produces either with skill A $\left(\lambda_{i}=1\right)$ or skill B $\left.\lambda_{i}=0\right)$.

${ }^{13}$ We deviate from Lazear's production function in order to model the decreasing marginal utility of one skill.
} 
could also have a positive effect on aggregated productivity, if all firms training for the same occupation have a very homogenous production process. In such a case, specialization would be counterproductive.

A modernization which implies a change in the degree of heterogeneity of the curriculum usually occurs because relevant stakeholders have requested this change. One main characteristic of the German apprenticeship system is the "consensus principle" which means that all relevant stakeholders involved in the apprenticeship system have to agree to a new training curriculum (Bundesinstitut für Berufsbildung 2014). Thus, we might expect that, when the number of choice options is changed, $\int_{i}^{N} \alpha-\lambda_{i}$ is smaller after a modernization than before the modernization. Under this assumption, any change in the degree of heterogeneity would lead to an increase in training places.

\section{Effect via firms' market power}

A change in the choice options in the training curriculum has additional effects on firms' post-training benefits via a change in their market power in the labor market for skilled workers. A more specific training curriculum creates monopsony power because it reduces the outside options of trained workers in the labor market as graduates can apply their skills in fewer outside firms. A significant share of firms employing skilled workers in the same occupation will prefer to hire a skilled worker with the reversed skill combination. Outside employers can observe the chosen specialization either on the apprenticeship leaving certificate, the work certificate, or the school certificate. Therefore, apprentices are more likely to stay in the training firm if they have been trained according to a more heterogeneous curriculum. This in turn increases firms' chances to recoup training investments incurred.

Moreover, firms are able to pay a lower wage relative to skilled workers' productivity. Let us assume that, in line with Lazear's argumentation, the wage the training firm has to pay after the training period is determined by a Nash bargaining process. Then, the wage lies exactly between the productivity of the graduates in the firm where they had been trained and their expected outside options. As the expected value of the outside options decreases in line with more heterogeneity in the curricula, the training firm is able to pay a lower wage. This increases the potential return obtained from offering training, which will lead to an increase in training places.

Both because of the higher productivity of trained workers in the training firm and the stronger bargaining power of the firm, more possibilities to specialize in the training curriculum will lead to higher returns for the firm after the training period. Therefore, we derive the following hypothesis. 
H2: More heterogeneity in the training curriculum increases the supply of apprenticeship places in this occupation.

With regard to the effect of less heterogeneity, we outlined two opposing effects. On the one hand, assuming that a change in the number of choice options leads to a better fit between acquired and demanded skills, less heterogeneity increases workers' productivity in the training firm. ${ }^{14}$. This would for example be the case if firms preferred to convey all skills to an equal degree and not to specialize in one skill. On the other hand, less heterogeneity will also decrease the bargaining power of the firm, something which leads to higher wages for trained workers. Accordingly, the general positive effect on the supply of a change in the degree of choice options would (partially) be compensated by lower relative wages and higher quit rates. It is not straightforward to see which of these two mechanisms has a stronger effect in practice. Therefore, no clear hypothesis on the effect of less heterogeneity can be derived.

\subsection{Demand for training places}

Equivalent to hypothesis 1, a modernization irrespective of the number of choice options is expected to have a positive effect on students' demand for apprenticeship places as trained apprentices will become more productive when the curriculum becomes more up to date. If the training fits better to the production process of the firm, apprentices will be more productive after completion of training, something which could increase skilled workers' wages in the firm providing training. This higher wage would make apprenticeship training in recently modernized occupations more attractive. Thus, we can derive the following hypothesis.

H3: A modernization of the training curriculum leads to a higher demand for apprenticeship places in this occupation.

A modernization which leads to more heterogeneity in the curriculum might have two opposing effects on students' demand for training places. On the one hand, more heterogeneity will lead to a better fit between the production process and the training

\footnotetext{
${ }^{14}$ This rests on the assumption that a change in the degree of choice options always leads to a better match between the training curriculum and a firm's needs.
} 
content which will make trained persons more productive and will therefore increase their wage in the training firm. On the other hand, apprenticeship graduates will then also become more specialized and more dependent on the training firm. This would ceteris paribus reduce their outside options and the wage they can earn in another firm. ${ }^{15}$ In case of a layoff, the apprentice would be more likely to suffer a wage loss. Therefore, more heterogeneity in the curriculum will reduce the graduates' bargaining power and their wage in the training firm. This makes an apprenticeship in occupations with a more heterogeneous curriculum less attractive.

The effect of more heterogeneity in the training curricula on the demand for apprenticeship places could therefore go in different directions, and we cannot derive a clear hypothesis. Nonetheless, even though theoretically the effect of heterogeneity in the training curricula on the demand for apprenticeship is not clear, we will assess this relationship empirically. With respect to the effect of a modernization leading to less heterogeneity on students' demand for apprenticeship places, both mechanisms could work in the same direction. If the lower number of choice options leads to a better fit between acquired and demanded skills, less heterogeneity will increase workers' productivity in the training firm. Moreover, less heterogeneity in the curriculum will improve graduates' bargaining power as they will then have more outside options. Therefore, we derive the following hypothesis.

H4: Less heterogeneity in the training curriculum increases the demand for apprenticeship places in this occupation.

\section{Data}

\subsection{Supply of and demand for apprenticeship places}

The data used for this analysis is based on the survey of New Training Contracts with the effective date of 30th of Sept of each training year. ${ }^{16}$ It includes information about the number of new training contracts and the supply of and demand for training contracts. The new training contracts are collated by the Bundesinstitut für Berufsbildung (BIBB) from the

\footnotetext{
${ }^{15}$ In this way more heterogeneity would lead to a lower outflow of trained graduates to other firms. Unfortunately, there is no data on the outflow of apprentices successfully completing training to other firms at the occupational level.

${ }^{16}$ For information about the survey see: http://www.bibb.de/dokumente/pdf/naa309 BIBBErhebung Zusammenfassung 201103.pdf
} 
responsible chambers, which have information on all new training contracts in their associated occupations. The supply of training contracts is calculated by adding the new training contracts of each year to the number of unfilled training places the firms report to the German Federal Employment Agency. The demand of apprenticeship places is obtained by adding the new training contracts to the number of applicants who could not get an apprenticeship place and did not have any other alternative. ${ }^{17}$ Thus, our database is a full census of the complete supply of and demand for apprenticeship places in Germany. Information about the supply of and demand for training contracts at the occupational level has been available since 2004 .

The data set comprises information on the supply of and the demand for all 330 occupations that were recognized ${ }^{18}$ in $2014 .{ }^{19}$ We had to gather information on the development of all occupations in order to construct a dataset with comparable occupations over time. ${ }^{20}$ When an occupation had a different name in the past or results from a merge of different occupations, it is linked to its predecessor(s) ${ }^{21}$. In the event that the occupation has had several predecessors, we use the sum of the supply (or demand) of training places of those predecessors and match this sum to the new occupation. ${ }^{22}$

We exclude very small occupations when the occupation comprised less than twelve apprentices in any of the years between 2004 and 2014. Moreover, we excluded eight occupations, which could not be compared over time due to a complex restructuring in the course of a modernization. ${ }^{23}$ In this way, we obtain a panel data set of 265 different occupations over eleven years. 244 occupations existed during the whole time period from 2004 to 2014, other were introduced at a later stage and therefore existed only during part of this period.

\footnotetext{
${ }^{17}$ The old definition of demand is used, to be able to compare the data between the years.

${ }^{18}$ All training regulations are published under the Federal Law Gazette ("Bundesgesetzblatt").

${ }^{19}$ This also excludes the possibility that occupations that were abandoned are still in the dataset.

${ }^{20}$ It is important that occupations which were modernized are comparable before and after the modernization. In some cases, occupations were split, which does not allow for a comparison over time. Those occupations were not part of the analysis.

${ }^{21}$ In our analyses we control for possible effects of a name change or mergers by including a name dummy as well as a dummy for mergers.

${ }^{22}$ As the data of the new training contracts are gathered by the chambers of industry and commerce and the chambers of craft, which sometimes incorrectly report the old name of the occupation, occupations that were not modernized in our research period also had to be matched to their predecessors.

${ }^{23}$ This is the case when occupations were split and the split parts were merged with other occupations.
} 


\subsection{Curriculum heterogeneity}

\subsubsection{Structure of the curricula}

We base the categorization of the degree of heterogeneity in the curricula on the structure of the training, which is defined for each occupation in the training regulation (see (Bundesinstitut für Berufsbildung 2014) ${ }^{24}$. Mono-occupations are occupations without any specialization. Thus, the training content is identical for all firms training the same occupation. On the other hand, there are also occupations whose curricula allow for internal differentiation. Then firms can chose between training courses with special training content for different fields of activity. For example, in some occupations firms have to choose different fields of application. Even though the concrete competencies that have to be taught are the same, they can be imparted in different fields. In other occupations, firms can chose priority topics, which take company characteristics into consideration and account for not more than 6 months out of the entire training period ${ }^{25}$. Even more differentiation is possible in occupations with different disciplines. A discipline is a specialization that has to be taken in the third training year and is also tested in the final exam in contrast to the priority topics. The highest degree of differentiation within an occupation is obtained by the use of elective qualification units. Usually several out of many possible units have to be chosen, which leads to a high number of different possible combinations within one occupation. In these occupations, firms have most possibilities to adapt the training content to their specific skill requirements. However, elective qualification units vary in the time they constitute of the total training time. In some occupations, they only account for half a training year, while in other occupations they account for a full training year. Bretschneider \& Schwarz (2011) provide a graphical overview of the different structures of training curricula (see Figure A1).

We ranked the five different training structures according to their degree of differentiation. Doing so, we take into account the number of specializations and the time these specializations take in relation to the total training time. The structure with elective qualification units, for example, allows for the highest number of possible combinations as firms can choose several out of many possible qualification units (see Figure $A 1$ in the appendix). In contrast, a structure including different disciplines means that firms can chose one discipline out of usually three or four disciplines. Therefore, the disciplines are mostly ranked lower than the qualification units. However, the internal differentiation is not only

\footnotetext{
${ }^{24}$ In the following, we use the terminology that is also employed in the English version of the official BIBB leaflet about training regulation (Bundesinstitut für Berufsbildung 2014).

${ }^{25}$ The entire training period can last between 2 and $31 / 2$ years.
} 
determined by the number of specializations but also by the importance these specializations have in relation to the total training content. For example, when a firm can chose between 100 specializations, but these specializations are only supposed to last for one week, they are likely to be not very relevant for the skill acquisition of the apprentice. Therefore, we also take into account the time these specializations take in relation to the total training time. As a result, when the elective qualification units account only for a relatively short time period (e.g. only half a year), they are ranked lower than the disciplines. According to the number and relevance of choice options, we yield the following ranking on the degree of heterogeneity for the different curricula structures from less to more heterogeneous: mono-occupations, fields of application, priority topics, elective qualification units (half a year) disciplines, and elective qualification units (full year).

\subsubsection{Defining the change in heterogeneity}

The amount of choice options, i.e. degree of heterogeneity, can only be changed in the course of a modernization. The operationalization of a modernization is straightforward as the result of a modernization is always the replacement of an old training curriculum by a new one. We allocated all modernizations into three groups: (1) modernizations creating less choice options in the curriculum, (2) modernizations that do not affect the choice options and (3) modernizations that allow for more curriculum heterogeneity.

In principle, changes in the degree of differentiation within an occupation can occur in four ways. Firstly, a curriculum could be given a different structure. For example, a change from e.g. a mono-occupation to an occupation with disciplines is defined as a change towards more heterogeneity. Secondly, the amount of possible specialization options can change within a given structure of the curriculum (e.g. a firm can chose between two instead of three possible disciplines). Thirdly, the time spend on existing specializations in the curriculum can change (elective qualification units should last one year instead of only half a year). Fourthly, when several occupations are merged into one occupation, the modernization is coded as less heterogeneity. ${ }^{26}$ Table A1 and Table A2 in the Appendix show the training structures and their respective number of choice options before and after the modernizations in the time period analyzed.

\footnotetext{
${ }^{26}$ We also included a separate dummy on mergers to test for potential separate effect of merged occupations. Splits of occupations are not part of our database.
} 
Table 1 provides an overview of how those modernizations in the different years are coded. In the period from the years 2005 to 2014, 103 modernizations were implemented, whereas 6 occupations were modernized twice. ${ }^{27}$ Thus, in these years 97 occupations were modernized. For our analysis, we can make use of 86 different modernizations. 8 modernizations had to be excluded because they led to a split and a merge of several occupations at the same time, something which impedes a comparison between the preand post-treatment period ${ }^{28}$, and 9 modernizations were excluded because they affected very small occupations with fewer than 12 apprentices. From the 86 modernized occupations, 22 became more homogenous, 26 became more heterogeneous and 38 did not change their structure at all. As can be seen in Table 1, in each year at least two modernizations occurred, with peaks in the years 2005, 2006 and 2013.

The information about the modernizations is obtained from the BIBB database on occupations and their modernizations, which is available online ${ }^{29}$. New training regulations always come into force in the month of August in the respective year. As the new training year always starts in September, all new training contracts reported in this year have to abide by the valid curricula of the respective year. For example, when the occupation "plant mechanic" is modernized in 2004, all firms concluding and reporting a new training contract for training the "plant mechanic" in 2004 have to train according to the new regulation.

\footnotetext{
${ }^{27}$ For occupations that were modernized in 2004, we cannot compare a pre- and post-modernization period.

${ }^{28}$ A detailed description of the unambiguous modernization is available upon request.

${ }^{29}$ https://www.bibb.de/de/berufeinfo.php/new modernised occupations by year
} 
Table 1: Curriculum modernizations between 2005 and 2014

\begin{tabular}{ccccc}
\hline \hline Year & Modernizations & $\begin{array}{c}\text { Less } \\
\text { heterogeneity }\end{array}$ & $\begin{array}{c}\text { No change in } \\
\text { heterogeneity }\end{array}$ & $\begin{array}{c}\text { More } \\
\text { heterogeneity }\end{array}$ \\
\hline \hline 2005 & 15 & $6(3)$ & 6 & 3 \\
2006 & 16 & $4(2)$ & 7 & 5 \\
2007 & 6 & $1(1)$ & 4 & 1 \\
2008 & 2 & $1(0)$ & 0 & 1 \\
2009 & 6 & $1(1)$ & 1 & 4 \\
2010 & 8 & $1(0)$ & 5 & 2 \\
2011 & 9 & $1(0)$ & 2 & 6 \\
2012 & 5 & $0(0)$ & 3 & 2 \\
2013 & 12 & $4(3)$ & 6 & 2 \\
2014 & 7 & $3(1)$ & 4 & 0 \\
\hline Total & 86 & $22(11)$ & 38 & 26 \\
\hline \hline
\end{tabular}

Note: The number of merged occupations leading to less heterogeneity is displayed in parentheses in the third column. Modernized occupations that were split cannot be compared over time. These occupations are not included in the analysis. Moreover, curriculum modernizations for very small occupations (with fewer than 12 apprentices) are also not included.

\section{Empirical strategy}

We first estimate occupational fixed-effect regressions in which we relate the supply of training places to the modernizations in the training curricula. To test the effect of changes in the degree of heterogeneity, we include two interaction terms indicating whether the modernization introduced more or less heterogeneity in the training curriculum. The occupational fixed-effect regression is therefore specified as follows:

$S_{o t}=o c c_{o}+\beta_{1} \bmod _{o t}+\beta_{2} h e t_{o t}+\beta_{2} h_{o m}+\delta_{t} d t+\gamma_{o} t_{o}+\varepsilon_{o t}$

$S_{o t}$ denotes the supply of apprenticeship places in year $t$ and occupation $o$. The indicator variable $o c c_{o}$ denotes the dummies for the different occupation. The variable $\bmod _{o t}$ is 1 if an occupation is modernized and 0 if it is not yet or has never been modernized. Thus, the parameter $\beta_{1}$ estimates the effect of the modernization itself. Six occupations were modernized twice in the time period analyzed. For these occupations, we used a second modernization dummy (not displayed in equation 3 ). To measure the effect of changes in curriculum heterogeneity, we include interaction terms indicating modernizations that allow for more heterogeneity $\left(\right.$ het $_{o t}$ ) and modernizations that lead to less heterogeneity, i.e. more homogeneity $\left(h_{o m_{o t}}\right)$. If the modernization implied a change towards more heterogeneity, het $t_{o t}$ takes the value 1 in the years after the modernization 
and 0 in the years before the modernization. When there was no change in the structure of the curriculum or when the number of choice options was reduced, the variable $h t_{o t}$ is always equal to 0 . The values for hom ot are analogous. Thus, $\beta_{1}$ and $\beta_{2}$ estimate the effect of more or less heterogeneity respectively. As controls, the following variables are included: year dummies $d t$ and occupation-specific time trends $t_{o}$. By the inclusion of the year dummies, we can exclude year specific exogenous shocks affecting the supply of apprenticeship places, such as cohort-specific demographic changes, changes in the number of school leavers and business cycle effects. The occupation-specific time trends control for any occupation specific upwards or downwards trend in the number of apprenticeships.

Analogously, we also run a regression in which we analyze to what extent more or less heterogeneity in the curriculum introduced by the modernization affects students' demand for apprenticeship places:

$D_{o t}=o c c_{o}+\beta_{1} \bmod _{o t}+\beta_{2} h_{e t}+\beta_{2} h_{o m}+\delta_{t} d t+\gamma_{o} t_{o}+\beta_{3}$ name $_{o t}+\varepsilon_{o t}$

This regression includes the same variables of interest and control variables as the training supply regressions. Moreover, we include an additional control variable name $e_{o t}$ which indicates whether or not the name of the occupation has been changed during the modernization. Correspondingly, $\beta_{3}$ estimates the effect of a name change. This variable measures potential changes in the attractiveness of the name of the occupation. Krewerth et al. (2004) show that the name of the occupation has a significant effect on the occupational choice of young school leavers. If policy makers choose a more attractive name, a name change might be associated with an increase in students' demand for apprenticeships.

\section{Results}

\subsection{Descriptive results}

First, we present some descriptive results on the relation between the modernizations and the supply of and demand for training places. Figure 1 shows average supply of and demand for training places over all occupations and years before and after the modernization differentiated by the three change categories: less heterogeneity, no change in the degree of heterogeneity and more heterogeneity. The values in the figure are based on the 86 modernizations in our period of analysis (See Table 1). Note that for each modernization the numbers of years before and after the modernization are different. For example, from the 22 occupations that became less heterogeneous after the modernization, 6 occupations were modernized in the year 2005 with only one observed pre-treatment year and 8 post treatment years. Similarly, for occupations that were modernized in the year 
2014, only one post-treatment year can be observed. Accordingly, the modernization of the years in between imply more or fewer pre- and post-treatment years respectively.

Figure 1 shows that a lower degree of heterogeneity is associated to an extreme decrease in both the supply of and demand for training places. However, this large decrease is particularly due to two very large occupations. Conversely, when the structure of the curriculum becomes more heterogeneous, supply of and demand for training places increase by $73 \%$ and $56 \%$, respectively. Also, when the curriculum structure does not change, both supply and demand show an increase after the modernization. These outcomes suggest that both firms and apprentices prefer more heterogeneity in the training regulation and dislike less heterogeneity. ${ }^{30}$

Figure 1: Demand for and supply of training places before and after the modernization

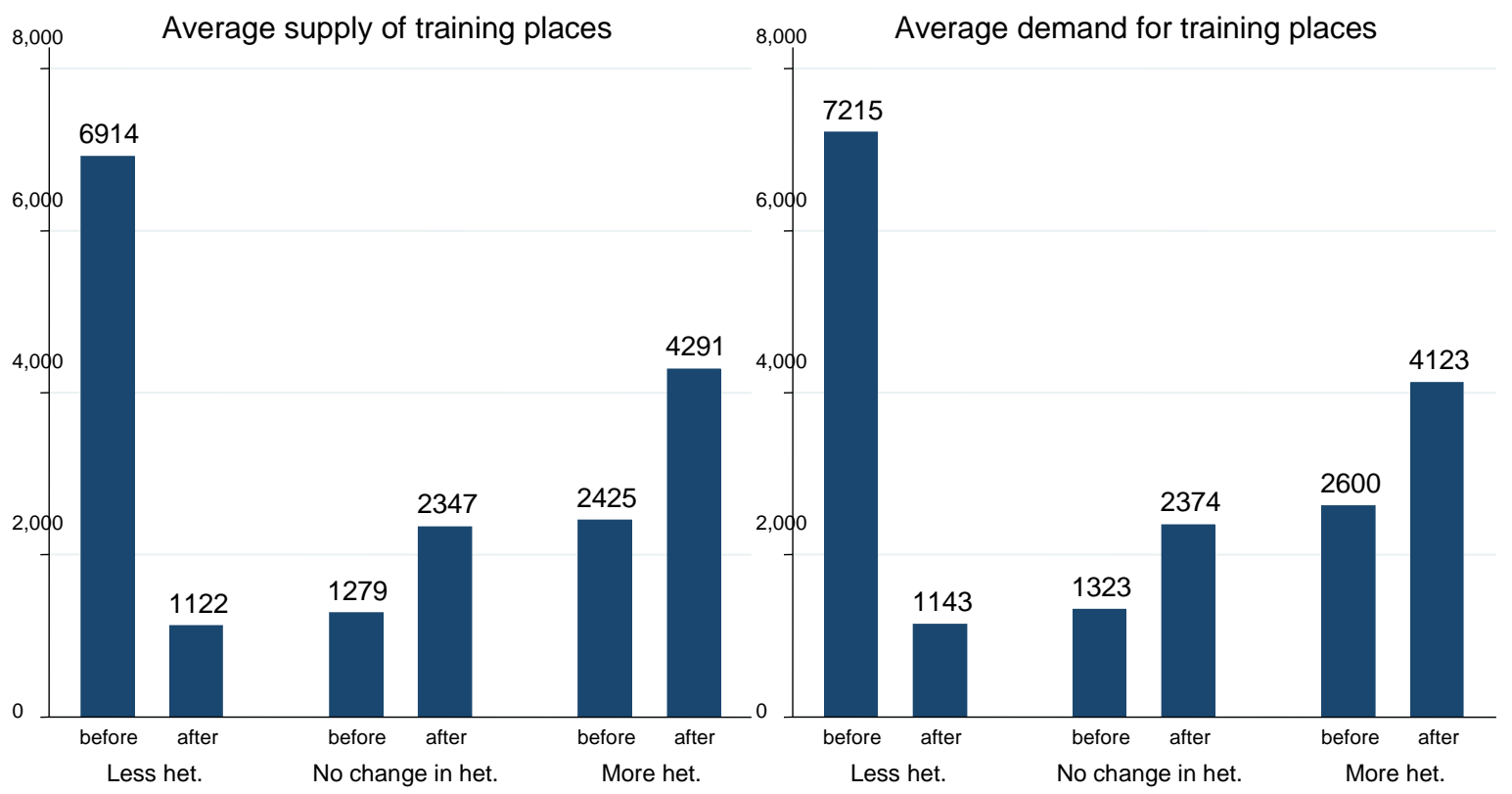

Note: The numbers refer to the average supply and demand over occupations as well as over the years before and after the modernization (het. = heterogeneity). Source: Demand and supply of training places in Germany. For this graphic, only the first modernizations are considered.

\footnotetext{
${ }^{30}$ This is in accordance with other findings that there are strong interdependencies between supply of and demand for apprenticeship places (Maier \& Walden 2014; Behringer \& Ulrich 1997).
} 


\subsection{Regression results}

Table 2 shows the estimation results of the occupation fixed-effect regression on the supply of and demand for apprenticeships respectively. As six occupations were modernized twice in the respective time period, we include a control dummy for the second modernization and interaction terms indicating whether or not the second modernization was associated with more (or less) heterogeneity.

The estimation results show that most of the time curriculum modernizations as such are not significantly associated with the supply of training places. Nonetheless, as the data source is a full census, the non-significant coefficients can also be interpreted meaningfully. ${ }^{31}$ The coefficient suggests that modernizations are slightly positively associated to firms' supply of training places. Considering the first modernizations, which make up $93 \%$ of all modernizations, a modernization as such is associated to an increase of the supply of 56 training places, which corresponds to $2.5 \%$ of the average supply of training places. ${ }^{32}$ In contrast, the six second modernizations even had a negative effect on the supply of training places with a coefficient of -183 .

Including the interaction variables on whether the modernizations were associated with more or less heterogeneity decreases the coefficient for the first modernizations and renders the coefficient for the second modernizations even more negative and significant at the five percent level. The coefficient for modernizations creating more heterogeneity is positive and significant at the $5 \%$ level. This is true for both the first modernization and also for the six second modernizations, whereas the coefficient of 1.057 for the second modernizations is much higher than the coefficient of 318 for the remaining 80 modernizations. However, considering the average supply of training places of 2,215, even the coefficient for the first modernization implies a substantial increase of $14 \%$. This shows that modernizations of the curriculum only successfully increase the supply of training places if firms receive more opportunities to adapt the curriculum to their needs. These results confirm hypotheses 2 and reject hypothesis 1 . These results also support the theory that the

\footnotetext{
${ }^{31}$ Usually the significance levels indicate the probability that this estimate is true in the population. In this case we have administrative data from the whole population, i.e. supply of new training contracts. For a description of the dataset please see (Flemming \& Granath 2011).

${ }^{32}$ The average supply of training places is 2,215 .
} 
effect is indeed channeled via the firm's post training benefits and not via the training costs. Training could become less costly after any modernization, but it is only the heterogeneity which leads to an increased wedge between productivity and wages.

The estimation results also show that modernizations that reduce the heterogeneity in the curriculum decrease the supply of training places by 209 , which is a decrease of $9 \%$. We also test for a separate effect of merged occupations by including a variable indicating whether the modernization consisted of a merger of occupations (column 3 ). The results show that the negative effect of less heterogeneity is mainly due to modernizations that combined several occupations into one. Including this control variable, the coefficient for less heterogeneity increases and the coefficient for the merge of occupation is -336 and significant at the $10 \%$ level. The coefficient, however, is much lower than what was suggested by the descriptive analysis in Figure 1 . This is probably due to the fact that occupations are often merged when they are on a downward trend anyway. As we control for occupation specific time trends in the regression analysis, the coefficient is lower than descriptive results suggest.

Table 2 also shows the estimation results on students' demand for training places (columns 4 to 6 ). These results seem to be rather similar. ${ }^{33}$ Students are more likely to apply for occupations that provide more heterogeneity in the training curriculum as the coefficient for more heterogeneity in the curricula is positive (205) and significant. Also the coefficient for the six second modernizations creating more heterogeneity is positive and significant at the 1 percent level. When comparing these results to the estimation results for the supply of apprenticeship places, one can see that the former coefficients are slightly smaller (at least for the first modernizations). This suggests that students' demand for apprenticeships is less sensitive to having more heterogeneity in the curriculum than the firm's supply.

Again, the modernization as such has an insignificant effect on the demand of training places. Moreover, modernizations which lead to more homogeneous curricula are not significantly related to the demand for apprenticeship places. Thus, we have to reject hypotheses 3 and 4 . The positive coefficient of more heterogeneity could suggest that more choice options always enhance the graduates' productivity.

\footnotetext{
${ }^{33}$ It is indeed not very surprising that the estimation results on supply and demand are closely related. Excess supply or demand is usually not large as the majority of all firms that supply apprenticeships also find apprentices and most students who would like to have an apprenticeship find one. When we regress the number of new apprenticeship contracts (i.e., matched supply and demand) on the same explanatory variables, the estimation results are indeed very similar.
} 
Table 2: Supply of and demand for apprenticeship places (occupation fixed-effects regressions)

\begin{tabular}{|c|c|c|c|c|c|c|}
\hline & $\begin{array}{c}\text { (1) } \\
\text { Supply }\end{array}$ & $\begin{array}{c}\text { (2) } \\
\text { Supply }\end{array}$ & $\begin{array}{c}\text { (3) } \\
\text { Supply }\end{array}$ & $\begin{array}{c}\text { (4) } \\
\text { Demand }\end{array}$ & $\begin{array}{c}(5) \\
\text { Demand }\end{array}$ & $\begin{array}{c}(6) \\
\text { Demand }\end{array}$ \\
\hline Modernized (before/after) & $\begin{array}{l}55.68 \\
(1.32)\end{array}$ & $\begin{array}{l}15.55 \\
(0.25)\end{array}$ & $\begin{array}{l}15.48 \\
(0.25)\end{array}$ & $\begin{array}{l}41.49 \\
(0.83)\end{array}$ & $\begin{array}{c}-0.94 \\
(-0.01)\end{array}$ & $\begin{array}{c}8.06 \\
(0.12)\end{array}$ \\
\hline More heterogeneity & & $\begin{array}{c}317.83^{* *} \\
(3.23)\end{array}$ & $\begin{array}{c}318.62^{\text {*** }} \\
(3.24)\end{array}$ & & $\begin{array}{c}205.47^{*} \\
(2.26)\end{array}$ & $\begin{array}{c}204.75^{*} \\
(2.25)\end{array}$ \\
\hline Less heterogeneity & & $\begin{array}{c}-209.41^{*} \\
(-2.01)\end{array}$ & $\begin{array}{l}-38.24 \\
(-0.28)\end{array}$ & & $\begin{array}{l}-57.68 \\
(-0.59)\end{array}$ & $\begin{array}{c}3.22 \\
(0.03)\end{array}$ \\
\hline Merge of occupations & & & $\begin{array}{c}-335.53^{*} \\
(-2.00)\end{array}$ & & & $\begin{array}{c}-125.60 \\
(-0.77)\end{array}$ \\
\hline Modernized (before/after) (2. Modernization) & $\begin{array}{c}-183.20 \\
(-1.06)\end{array}$ & $\begin{array}{c}-794.78^{* *} \\
(-2.81)\end{array}$ & $\begin{array}{c}-794.82^{* *} \\
(-2.81)\end{array}$ & $\begin{array}{c}-922.74^{* * *} \\
(-4.50)\end{array}$ & $\begin{array}{c}-1444.62^{* * * *} \\
(-5.54)\end{array}$ & $\begin{array}{c}-1446.49^{* * * *} \\
(-5.54)\end{array}$ \\
\hline More heterogeneity (2. Modernization) & & $\begin{array}{c}1057.13^{\text {*** }} \\
(2.76)\end{array}$ & $\begin{array}{c}1085.89^{* * *} \\
(2.83)\end{array}$ & & $\begin{array}{c}1461.85^{* * * *} \\
(3.49)\end{array}$ & $\begin{array}{c}1458.16^{* * * *} \\
(3.49)\end{array}$ \\
\hline Less heterogeneity (2. Modernization) & & $\begin{array}{c}939.88 \\
(1.92)\end{array}$ & $\begin{array}{c}939.96 \\
(1.92)\end{array}$ & & $\begin{array}{c}1162.70 \\
(1.77)\end{array}$ & $\begin{array}{c}1137.38 \\
(1.73)\end{array}$ \\
\hline Year dummies (Reference 2004) & & & & & & \\
\hline 2005 & $\begin{array}{l}-9.96 \\
(-0.02)\end{array}$ & $\begin{array}{l}-11.74 \\
(-0.03)\end{array}$ & $\begin{array}{l}-11.16 \\
(-0.02)\end{array}$ & $\begin{array}{l}-10.74 \\
(-0.02)\end{array}$ & $\begin{array}{l}-12.73 \\
(-0.03)\end{array}$ & $\begin{array}{l}-12.47 \\
(-0.03)\end{array}$ \\
\hline 2006 & $\begin{array}{l}174.52 \\
(0.19)\end{array}$ & $\begin{array}{l}166.77 \\
(0.18)\end{array}$ & $\begin{array}{l}167.95 \\
(0.18)\end{array}$ & $\begin{array}{c}206.30 \\
(0.24)\end{array}$ & $\begin{array}{l}200.34 \\
(0.23)\end{array}$ & $\begin{array}{l}201.06 \\
(0.23)\end{array}$ \\
\hline 2007 & $\begin{array}{c}459.99 \\
(0.33)\end{array}$ & $\begin{array}{c}446.22 \\
(0.32)\end{array}$ & $\begin{array}{l}448.07 \\
(0.32)\end{array}$ & $\begin{array}{c}428.52 \\
(0.33)\end{array}$ & $\begin{array}{l}419.04 \\
(0.32)\end{array}$ & $\begin{array}{l}419.93 \\
(0.32)\end{array}$ \\
\hline 2008 & $\begin{array}{c}499.61 \\
(0.27)\end{array}$ & $\begin{array}{c}480.16 \\
(0.26)\end{array}$ & $\begin{array}{c}482.01 \\
(0.26)\end{array}$ & $\begin{array}{c}403.31 \\
(0.23)\end{array}$ & $\begin{array}{c}390.05 \\
(0.23)\end{array}$ & $\begin{array}{c}390.84 \\
(0.23)\end{array}$ \\
\hline 2009 & $\begin{array}{c}377.82 \\
(0.16)\end{array}$ & $\begin{array}{c}351.77 \\
(0.15)\end{array}$ & $\begin{array}{c}354.91 \\
(0.15)\end{array}$ & $\begin{array}{c}306.61 \\
(0.14)\end{array}$ & $\begin{array}{c}289.63 \\
(0.13)\end{array}$ & $\begin{array}{c}290.85 \\
(0.14)\end{array}$ \\
\hline 2010 & $\begin{array}{c}459.92 \\
(0.16)\end{array}$ & $\begin{array}{c}425.66 \\
(0.15)\end{array}$ & $\begin{array}{l}429.47 \\
(0.15)\end{array}$ & $\begin{array}{c}375.65 \\
(0.14)\end{array}$ & $\begin{array}{c}355.32 \\
(0.14)\end{array}$ & $\begin{array}{c}356.67 \\
(0.14)\end{array}$ \\
\hline
\end{tabular}




\begin{tabular}{|c|c|c|c|c|c|c|}
\hline 2011 & $\begin{array}{c}613.44 \\
(0.19)\end{array}$ & $\begin{array}{c}567.84 \\
(0.17)\end{array}$ & $\begin{array}{c}571.55 \\
(0.17)\end{array}$ & $\begin{array}{c}497.88 \\
(0.16)\end{array}$ & $\begin{array}{c}471.10 \\
(0.16)\end{array}$ & $\begin{array}{c}472.30 \\
(0.16)\end{array}$ \\
\hline \multirow[t]{2}{*}{2012} & 642.75 & 589.26 & 593.53 & 541.10 & 507.02 & 508.37 \\
\hline & $(0.17)$ & $(0.16)$ & $(0.16)$ & $(0.16)$ & $(0.15)$ & $(0.15)$ \\
\hline \multirow[t]{2}{*}{2013} & 642.71 & 586.20 & 592.36 & 569.85 & 533.42 & 535.28 \\
\hline & $(0.15)$ & $(0.14)$ & $(0.14)$ & $(0.15)$ & $(0.14)$ & $(0.14)$ \\
\hline \multirow[t]{2}{*}{2014} & 710.71 & 654.20 & 660.36 & 637.85 & 601.42 & 603.28 \\
\hline & $(0.15)$ & $(0.14)$ & $(0.14)$ & $(0.15)$ & $(0.14)$ & $(0.14)$ \\
\hline \multirow[t]{2}{*}{ Name change } & & & & -49.17 & -50.39 & -70.04 \\
\hline & & & & $(-0.63)$ & $(-0.64)$ & $(-0.84)$ \\
\hline \multirow[t]{2}{*}{ Name change (2. Modernization) } & & & & $1219.16^{* * *}$ & 397.90 & 421.79 \\
\hline & & & & $(3.74)$ & $(0.83)$ & $(0.88)$ \\
\hline \multirow[t]{2}{*}{ Constant } & 166445.89 & 155262.24 & 156608.42 & 186269.15 & 179077.74 & 179463.72 \\
\hline & $(0.18)$ & $(0.17)$ & $(0.17)$ & $(0.22)$ & $(0.21)$ & $(0.21)$ \\
\hline Occupation-specific year trends & yes & yes & yes & yes & yes & yes \\
\hline Occupation FE & yes & yes & yes & yes & yes & yes \\
\hline Number of occupations & 265 & 265 & 265 & 265 & 265 & 265 \\
\hline Observations & 2843 & 2843 & 2843 & 2843 & 2843 & 2843 \\
\hline $\mathrm{R} 2$ & 0.69 & 0.69 & 0.69 & 0.79 & 0.80 & 0.80 \\
\hline
\end{tabular}

Note: $\mathrm{T}$-statistics in parentheses, $* * * \mathrm{p}<0.01, * * \mathrm{p}<0.05, * \mathrm{p}<0.1$. 


\subsection{Robustness test}

\section{Only a temporary effect?}

In order to test whether the effect of the modernization is particularly large in the first year after the modernization and levels off in the following years, we created a variable which is one for the immediate year after the modernization and zero in all other years. We further created two variables indicating the interaction between the first year after the modernization and the change towards more or less heterogeneity. The variables are again 1 for the year immediately after the modernization that leads to more (or less) heterogeneity and zero in all other years. We estimated the two baseline regressions for supply and demand (shown again in column 1 and 4 of Table 3), respectively ${ }^{34}$, including these control variables (see columns 2 and 5 of Table 3). The estimation results show that the first year after the modernization does not have any significant effect on firms' supply of or students' demand for apprenticeship places. Moreover, in both the supply and demand regressions, the estimation results on the effects of modernization remain robust showing that more heterogeneity in the curriculum increases both supply and demand for apprenticeship places.

\section{Anticipation effect before the modernization}

The increase in supply and demand after modernizations that increase curriculum heterogeneity could also be due to a dip in the supply and/or demand in the year before the modernization, if firms and students anticipated the modernization and postponed the training to the next year when the modernized curriculum was introduced. To test whether this could be a driver of the effects of the modernization, we also added a dummy variable for the year immediately before the modernization to the baseline regression. Again, we also construct interaction terms, which differentiate between modernizations creating more and less heterogeneity. The estimation results presented in Table 3 (column 3 and 6) show that the coefficients for modernization creating more heterogeneity even become larger, whereas the coefficients of the dummy variable for the last year before the modernization with more heterogeneity are also significantly positive. This suggests that firms already tend to increase their supply of apprenticeships one year before the modernization anticipating that the training curricula will be modernized and more choice options will be introduced.

\footnotetext{
${ }^{34}$ If we take the regression in column 3 and 6 of Table 2 as baseline regressions, including these control variables has similar effects.
} 
Table 3: Supply and demand for apprenticeship places (occupation fixed-effects regressions controlling for anticipation and short-term effects)

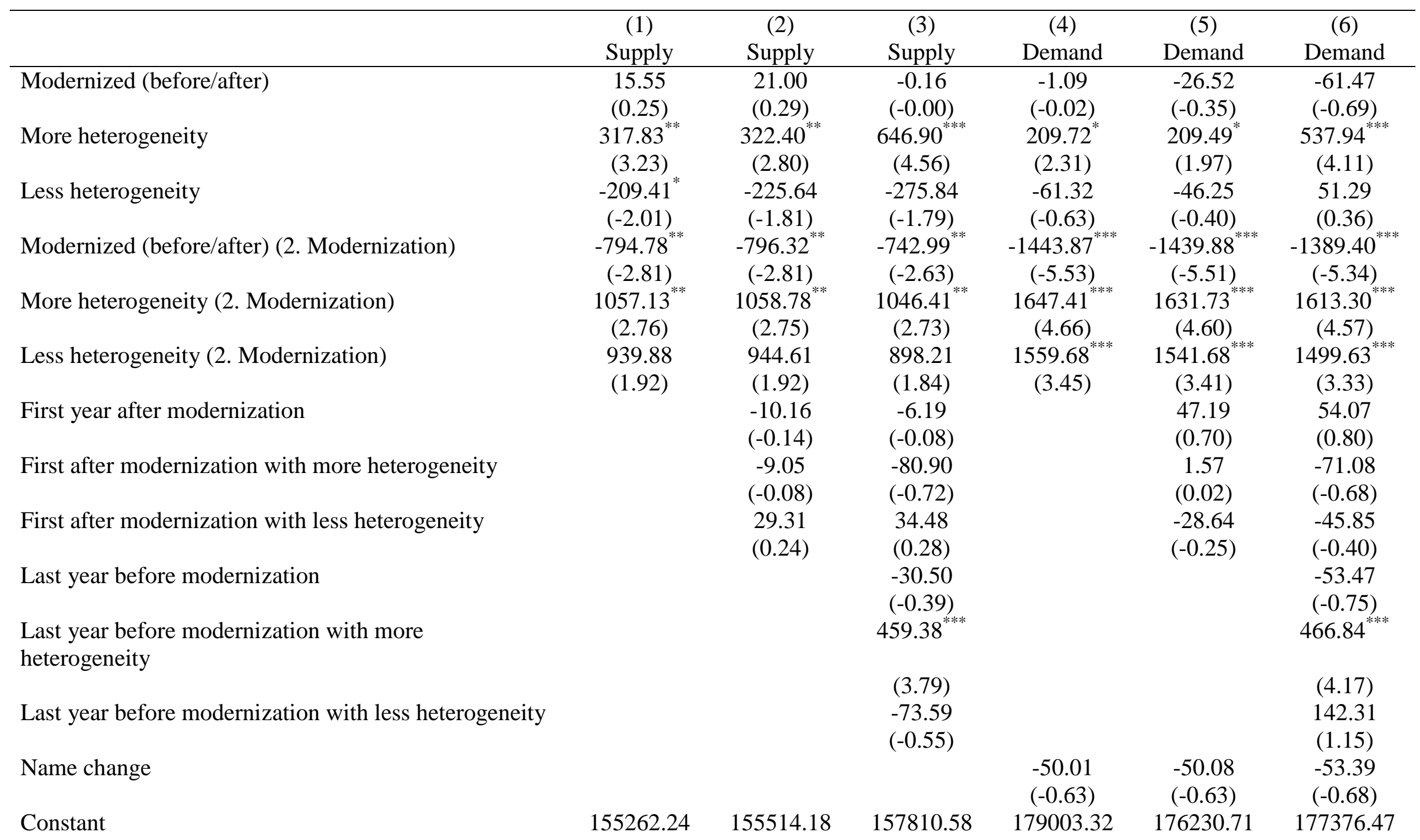




\begin{tabular}{|c|c|c|c|c|c|c|}
\hline & $(0.17)$ & $(0.17)$ & $(0.17)$ & $(0.21)$ & $(0.20)$ & $(0.21)$ \\
\hline Number of occupations & 265 & 265 & 265 & 265 & 265 & 265 \\
\hline Observations & 2843 & 2843 & 2843 & 2843 & 2843 & 2843 \\
\hline
\end{tabular}

Note: T-statistics in parentheses, $* * * \mathrm{p}<0.01, * * \mathrm{p}<0.05, * \mathrm{p}<0.1$. 


\section{Conclusion}

In this paper, we analyzed the effect of heterogeneity within training curricula on the supply of and demand for apprenticeship training places. We make use of the modernizations of training curricula to find the effect of creating more or less heterogeneity in the contents of a training curriculum. We find that more heterogeneity in a training curriculum increases both supply and demand for training places in the occupation.

Modernizations of training curricula are a relatively exogenous change of the institutional training framework. However, one might argue that choice options could be introduced in the same year of other unobserved changes that might affect the supply or demand for apprenticeship places. Such changes could refer to the business cycle or the demographic situation. However, by including year dummies and occupation-specific time trends, we can rule out a substantial amount of potential endogeneity. Moreover, the exact year of the modernized regulation can be seen as relatively random as occupations are not regularly modernized.

Our estimation results show that introducing more heterogeneity in a training curriculum increases the number of apprenticeship places offered by firms as well as students' demand for these places. This suggests that having a curriculum that fits more closely to the requirements of a firm's production process is necessary to ensure the attractiveness of the dual system both for the firm and the apprentice. A modernization, which improves the match between the content of the curriculum and firms' training needs, makes apprenticeship training more effective and graduated apprentices more productive. As the production processes of firms are often quite diverse, it is recommendable to allow for sufficient choice options in the training curriculum when a modernization is implemented. Firms are willing to offer more training places when they can expect higher post-training benefits from their apprentices. Moreover, more specific curricula also increase the market power of firms, something which enables them to pay wages that are below workers' productivity.

However, we find that the beneficial effect of more heterogeneity in the training curricula for the firms does not lead to a decrease in potential students' demand for apprenticeships. Instead, we find that a more heterogeneous curriculum also increases students' demand for apprenticeship places. This might be explained by a positive net effect 
of heterogeneity on skilled worker wages when they acquire more skills that they can apply in their job instead of skills they could not use in the firm where they are employed. ${ }^{35}$

While a sufficient number of choice options is important for the attractiveness of a curriculum for both firms and apprentices, it might also be important to ensure a certain standardization, because too much heterogeneity will give graduated apprentices very few chances outside their training firm. Also for firms, some standardization of the contents of the training curriculum could have positive effects. When firms search for workers on the external labor market, they will benefit from a higher number of apprenticeship graduates that could potentially work in their firm. In contrast, having too much heterogeneity would restrict the possibilities to recruit skilled workers from other firms. The number of suitable skilled workers would then fully depend on the firm's own engagement in apprenticeship training. Our findings show that the modernizations that increased heterogeneity in the curricula of apprenticeship training in Germany retained sufficient standardization to prevent these potential adverse effects.

\footnotetext{
${ }^{35}$ The available data does not allow us to estimate the effect of heterogeneity on skilled worker wages.
} 


\section{References}

Acemoglu, D. \& Pischke, J.-S., 1999. Beyond Becker: Training in imperfect labour markets. The Economic Journal, 109(453), pp.F112-F142.

Acemoglu, D. \& Pischke, J.-S., 1999. The Structure of Wages and Investment in General Training. Journal of Political Economy, 107(3), pp.539-572.

Becker, G.S., 1962. Investment in Human Capital: A Theoretical Analysis. The Journal of Political Economy, 70(5), pp.9-49.

Behringer, F. \& Ulrich, J.G., 1997. Die Angebotsabhängigkeit der Nachfrage nach Ausbildungsstellen als Problem bei der Vorausschätzung der zukünftigen Nachfrage. Mitteilungen aus der Arbeitsmarkt- und Berufsforschung, 3.

Bhaskar, V., Manning, A. \& To, T., 2002. Oligopsony and Monopsonistic Competition in Labor Markets. Journal of Economic Perspectives, 16(2), pp.155-174.

Bretschneider, M. \& Schwarz, H., 2011. Berufsbildung in Unordnung? Strukturierung von Ausbildungsberufen. Berufsbildung in Wissenschaft und Praxis, 2, pp.43-46.

Bundesinstitut für Berufsbildung, 2014. Training regulation and how they come about A. M. Kuppe et al., eds., Bonn: Federal Institute for Vocational Education and Training.

Demgenski, C. \& Icks, A., 2003. Der Umgang des Mittelstands mit neugestalteten und modernisierten Ausbildungsordnungen. IfM-Materialien, No. 156.

Dietrich, H. \& Gerner, H., 2007. The determinants of apprenticeship training with particular reference to business expectations. Journal of Labor Market Research, 40(2-3), pp.221233.

Dionisius, R. et al., 2009. Costs and Benefits of Apprenticeship Training. A Comparison of Germany and Switzerland. Applied Economics Quarterly, 55(1), pp.7-37.

Flemming, S. \& Granath, R., 2011. Die BIBB-Erhebung über neu abgeschlossene Ausbildungsverträge zum 30 . September, Bonn: Bundesinstitut für Berufsbildung (BIBB).

Geel, R., Mure, J. \& Backes-Gellner, U., 2011. Specificity of occupational training and occupational mobility: an empirical study based on Lazear's skill-weights approach. Education Economics, 19(5), pp.519-535.

Hall, A., 2015. Berufswechsel nach der Ausbildung : 18- bis 24-Jährige mit dualer Berufsausbildung im Erwerbsleben. Berufsbildung in Wissenschaft und Praxis, 2, pp.4-5.

Hofmann, J., Damelang, A. \& Schulz, F., 2011. Strukturmerkmale von Berufen Einfluss auf die berufliche Mobilität von Ausbildungsabsolventen. IAB Forschungsbericht, 9.

Krewerth, A. et al., 2004. Berufsbezeichnungen und ihr Einfluss auf die Berufswahl von Jugendlichen. Theoretische Überlegungen und empirische Ergebnisse. In Berichte zur beruflichen Bildung (Heft 270). Bielefeld: Bertelsmann.

Lazear, E.P., 2009. Firm-Specific Human Capital: A Skill-Weights Approach. Journal of Political Economy, 117(5), pp.914-940.

Maier, T. \& Walden, G., 2014. The influence of demographic factors on the supply of 
company training places in Germany. Empirical Research in Vocational Education and Training, 6(4).

Merrilees, W.J., 1983. Alternative Models of Apprentice Recruitment: With Special Reference to the British Engineering Industry. Applied Economics, 15(1), pp.1-21.

Mühlemann, S., Wolter, S.C. \& Wüest, A., 2009. Apprenticeship Training and the Business Cycle. Empirical Research in Vocational Education and Training, 1(2), pp.173-186(14).

Ramboll Management, 2005. Was muss sich an Ausbildungsordnungen ändern, damit Unternehmen mehr ausbilden? Bundesministerium für Wirtschaft und Arbeit, ed. Abschlussbericht.

Schönfeld, G. et al., 2010. Kosten und Nutzen der dualen Ausbildung aus Sicht der Betriebe. Ergebnisse der vierten BIBB-Kosten-Nutzen-Erhebung Bundesinstitut für Berufsbildung, ed., Bielefeld.

Smits, W., 2007. Industry-specific or generic skills? Conflicting interests of firms and workers. Labour Economics, 14(3), pp.653-663.

Stevens, M., 1994. A Theoretical Model of On-the-Job Training with Imperfect Competition. Oxford Economic Papers, 46(4), pp.537-562.

Troltsch, K. \& Walden, G., 2010. Beschäftigungsentwicklung und Dynamik des betrieblichen Ausbildungsangebotes. Eine Analyse für den Zeitraum 1999 bis 2008. Zeitschrift für Arbeitsmarktforschung, 43(2), pp.107-124.

Uhly, A., 2015. Alter der Auszubildenden und Ausbildungsbeteiligung der Jugendlichen im dualen System. In Datenreport zum Berufsbildungsbericht. Bonn: Bundesinstitut für Berufsbildung, pp. $163-171$.

Wolter, S.C. \& Ryan, P., 2011. Apprenticeship. In E. A. Hanushek, S. Machin, \& L. Woessmann, eds. Handbook of the Economics of Education Vol. 3. The Netherlands: North-Holland, pp. 521-576. 


\section{Appendix}

Table A1: Modernizations leading to less heterogeneity

\begin{tabular}{|c|c|c|c|}
\hline \multirow[b]{2}{*}{ Year } & \multicolumn{2}{|c|}{ Number and type of choice options } & \multirow[b]{2}{*}{ Merger } \\
\hline & Before modernization & After modernization & \\
\hline \multirow{6}{*}{2005} & Disciplines (1 out of 3 ) & Priority topics (1 out of 3 ) & No \\
\hline & 2 Disciplines & Mono-occupation & No \\
\hline & 12 predecessor occupations & & Yes \\
\hline & 2 predecessor occupations & & Yes \\
\hline & 3 predecessor occupations & Disciplines & Yes \\
\hline & $\begin{array}{l}\text { Disciplines ( } 1 \text { out of } 2)+ \text { fields of } \\
\text { application ( } 1 \text { out of } 3 \text { ) }\end{array}$ & Fields of application (1 out of 3 ) & No \\
\hline \multirow{5}{*}{2006} & Disciplines & Priority topics & No \\
\hline & 2 predecessor occupations & Mono-occupation & Yes \\
\hline & Disciplines ( 1 out of 6 ) & Disciplines (1 out of 2 ) & No \\
\hline & Priority topics (1 out of 2 ) & Mono-occupation & No \\
\hline & 2 predecessor occupations & Mono-occupation & Yes \\
\hline 2007 & 3 predecessor occupations & Disciplines (1 out of 3 ) & Yes \\
\hline 2008 & Fields of application (1 out of 4 ) & Mono-occupation & No \\
\hline 2009 & Two predecessor occupations & Disciplines (1 out of 3 ) & Yes \\
\hline 2010 & Specialized fields (1 out of two) 52 Weeks & $\begin{array}{l}\text { Elective qualification units ( } 2 \text { out } \\
\text { of 12) } 26 \text { Weeks }\end{array}$ & No \\
\hline \multirow[t]{2}{*}{2011} & $\begin{array}{l}\text { Elective qualification units } \\
(2 \text { out of } 5)+(2 \text { out of } 8)+(1 \text { out of } 7) \\
(44 \text { weeks) }\end{array}$ & $\begin{array}{l}\text { Elective qualification units ( } 2 \text { out } \\
\text { of } 11)+(1 \text { out of } 7) \text { ( } 52 \text { weeks) }\end{array}$ & No \\
\hline & Three predecessor occupations & Disciplines & Yes \\
\hline 2012 & Various predecessor occupations & 4 Disciplines & Yes \\
\hline \multirow{3}{*}{2013} & 5 Fields of application & 4 Fields of application & No \\
\hline & Various predecessor occupations & 5 Priority topics & Yes \\
\hline & Various predecessor occupations & 3 Disciplines & Yes \\
\hline \multirow{3}{*}{2014} & 3 Disciplines & 2 Disciplines & No \\
\hline & Various predecessor occupations & $\begin{array}{l}2 \text { from } 10 \text { elective qualification } \\
\text { units }\end{array}$ & Yes \\
\hline & 3 Disciplines & 5 Priority topics & No \\
\hline
\end{tabular}


Table A2: Modernizations leading to more heterogeneity

\begin{tabular}{|c|c|c|}
\hline \multirow[b]{2}{*}{ Year } & \multicolumn{2}{|c|}{ Number and type of choice options } \\
\hline & Before modernization & After modernization \\
\hline \multirow{3}{*}{2005} & Disciplines (1 out of 3 ) & Elective qualification units ( 2 out of 6 ) \\
\hline & Mono-occupation (3 alternatives) & Mono-occupation (4 alternatives) \\
\hline & Mono-occupation & Discipline (1 out of five) \\
\hline \multirow{5}{*}{2006} & Priority topics (1 out of 2 ) & Priority topics (1 out of 3 ) \\
\hline & Mono-occupation & Elective qualification units ( 2 out of 5 ) \\
\hline & $\begin{array}{l}\text { Mono-occupation with elective modules ( } 2 \text { out } \\
\text { of } 3 \text { modules) }\end{array}$ & Discipline (1 out of 2 ) \\
\hline & Mono-occupation & Fields of application (1 out of 10 ) \\
\hline & Mono-occupation with 4 Priority topics & Mono-occupation with 6 priority topics \\
\hline 2007 & $\begin{array}{l}\text { Elective qualification units ( } 1 \text { out of } 4)+(4 \text { out } \\
\text { of } 7 \text { ) }\end{array}$ & $\begin{array}{l}\text { Elective qualification units ( } 1 \text { out of } 4)+(4 \text { out of } \\
8 \text { ) }\end{array}$ \\
\hline \multirow{2}{*}{2008} & Mono-occupation & Elective qualification units ( 1 out of 5 ) \\
\hline & Mono-occupation & Priority topics ( 1 out of 3 ) \\
\hline \multirow{4}{*}{2009} & Mono-occupation & Discipline (1 out of 2$)$ \\
\hline & Mono-occupation & Priority topics ( 1 out of 4 ) \\
\hline & Discipline (1 out of 3 ) & Elective qualification units ( 1 out of 6 ) \\
\hline & Mono-occupation & Elective qualification units \\
\hline \multirow{2}{*}{2010} & Priority topics (1 out of 3 ) & Priority topics (1 out of 4 ) \\
\hline & Priority topics (1 out of 4 ) & Discipline (1 out of 5 ) \\
\hline \multirow{6}{*}{2011} & Mono-occupation & Specialized fields (1 out of 2 ) \\
\hline & Discipline (1out of 3) & $\begin{array}{l}\text { Elective qualification units ( } 2 \text { out of } 9)+(1 \text { out of } \\
\text { 2) }\end{array}$ \\
\hline & Priority topics & Elective qualification units ( 1 out of 3 ) \\
\hline & Discipline & Elective qualification units \\
\hline & Elective qualification units ( 2 out of 8 ) & $\begin{array}{l}\text { Elective qualification units ( } 2 \text { out of } 4)+(2 \text { out of } \\
6 \text { ) }\end{array}$ \\
\hline & Fields of application (1 out of 3 ) & Elective qualification units ( 1 out of 3 ) \\
\hline \multirow{2}{*}{2012} & Mono-occupation & Priority topics (1 out of 2 ) \\
\hline & Priority topics (1 out of 6 ) & Disciplines (1 out of 7 ) \\
\hline \multirow{3}{*}{2013} & Mono-occupation & Priority topics (1 out of 3 ) \\
\hline & Mono-occupation & Fields of application (1 out of 7) \\
\hline & Mono-occupation & Disciplines (1 out 4 ) \\
\hline 2014 & Mono-occupation & Disciplines (1 out of 2 ) \\
\hline
\end{tabular}


Figure A1: Structures of the curricula
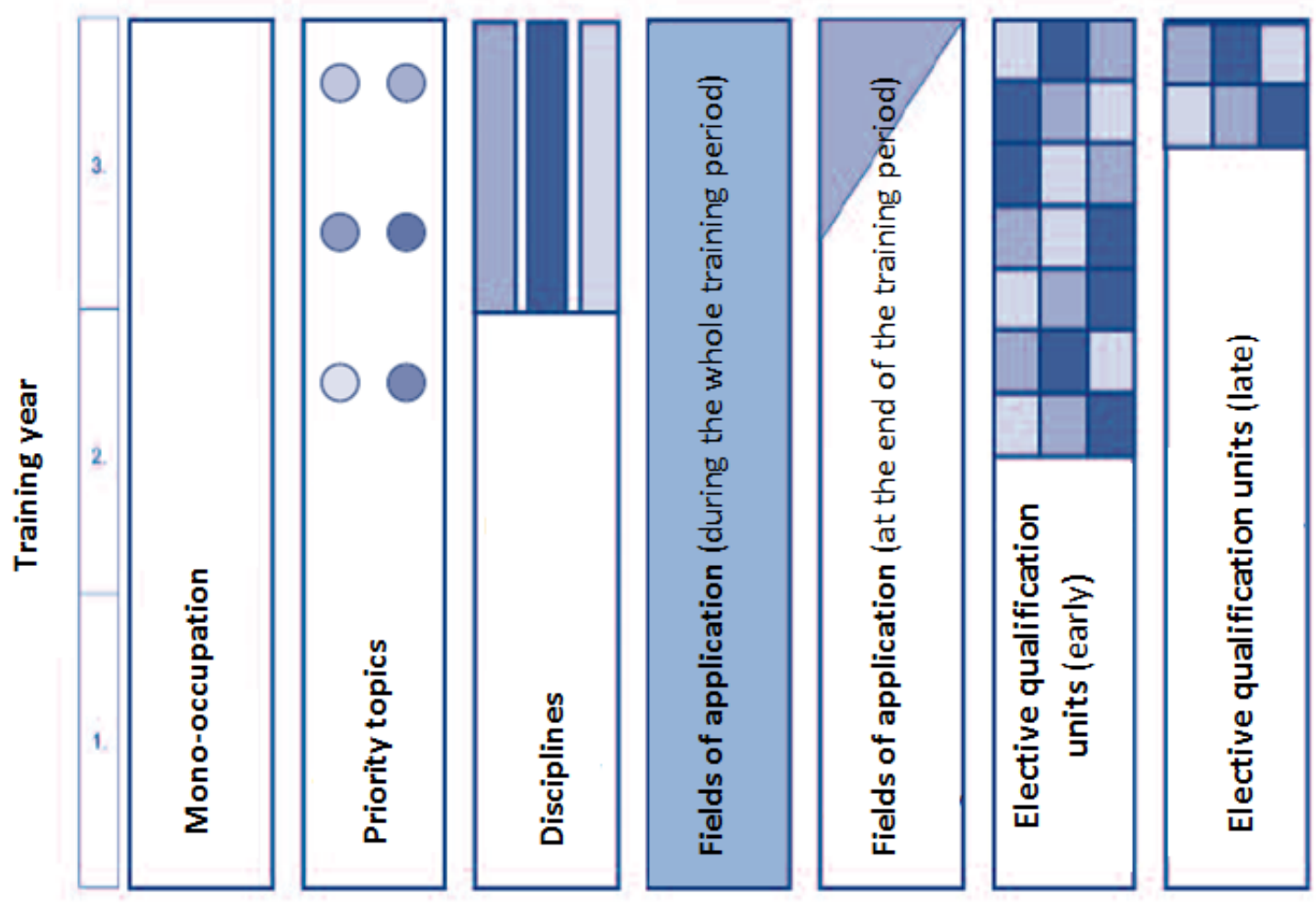

Note: Translated from Bretschneider \& Schwarz (2011) 